\title{
Effect of Nitrogen Fertilizers forms on Fruit Yield and Quality of Squash Plants. (Cucurbitapepo)
}

Badr, L. A. A., F. A. Abo-Sedera, M. A. El-Nagar and Arab I. M. Zeinab.

Horticulture Department, Faculty of Agriculture, Benha University

\begin{abstract}
Two field experiments were carried out during the two successive summer seasons of 2016 and 2017 at the vegetable farm of the faculty of Agriculture Moshtohor, Benha University, Egypt to investigate the response of Squash plant $\mathrm{Cv}$. Eskandrani to mineral, organic and bio fertilization on fruit yield and its components as well as fruit quality. The experimental treatments of mineral, organic and bio fertilization in single or combined application were conducted as follows:-100\% mineral nitrogen fertilizer from recommend dose $(200 \mathrm{~kg}$ ammonium nitrate per feddan), $75 \%$ mineral nitrogen plus $25 \%$ organic manure in the form of compost, $50 \%$ mineral nitrogen plus $50 \%$ organic manure, $25 \%$ mineral nitrogen plus $75 \%$ organic manure, $100 \%$ organic manure (compost), $100 \%$ organic manure (compost) plus addition of phosphorine at rate of $500 \mathrm{~g} / \mathrm{fed}$ plus Nitrobein bio- fertilizer at rate of $400 \mathrm{~g} / \mathrm{fed}$.. Obtained results showed that, There were a significant differences among the studied nitrogen fertilizer treatments on all determined yield and its components and fruit quality during the two seasons of growth. In this concern, fertilizing squash plants with $100 \%$ mineral nitrogen fertilizer only reflected the highest values of number of fruit per plant, fruit yield per plant and total fruit yield per feddan compared with other nitrogen fertilizer treatments. The highest values of fruit length, diameter and weight were recorded from $100 \%$ mineral nitrogen of recommended dose, followed by $100 \%$ organic manure treatments, followed by $75 \%$ mineral nitrogen plus $25 \%$ organic manure.
\end{abstract}

Keywords: squash mineral nitrogen fertilizer organic compost bio

\section{Introduction}

Squash is one of the most important vegetable crops in Egypt. Squash plants as a member of the family of cucurbitacea is a highly polymorphic vegetable (Kathiravanet al. 2006), Squash is contains a lot of nutrients and bioactive compounds such as flavonoids, antioxidants, vitamins (B complex group and A, B-carotene, amino acids, carbohydrates, and minerals (especially, K). Mover; it contains protein 1.0gm, carbohydrates $11.69 \mathrm{gm}$ (Tamer et al. 2010). It has various health and medicinal benefits to human such as comprising antidiabectic, antitumor, ant mutagenic, and ant inflammation (Kostalova et al. 2009 and Mohammad et al. 2011). The total area devoted to grow squash in Egypt was increased and reached about 44972 fed. With an average yield of 7.9 ton/ fed. According to the statistics of Egyptian Ministry of Agriculture and land reclamation in 2017 season.

There is important need for scientific studies under Egyptian conditions to establish recommendation for reducing the chemical fertilizers addition to increase the quantity, improve the quality and limit the environmental pollution by using organic and bio fertilization. Nitrogen is an important nutrient for squash production. However there is scanty information about the amount necessary to maintain an appropriate balance between growth and yield. Organic manures, particularly compost have traditionally been used by potato farmers. The use of organic matter to meet the nutrient requirement of crops would be an inevitable practice in years to come, particularly for resource poor farmers.
Furthermore, ecological and environmental concerns over the increased and indiscriminated use of inorganic fertilizers have made research on use of organic materials as a source of nutrients very necessary (Upadhyaya et al., 2003). Organic manures like compost can play an important role in potato productivity. These sources can reduce the diffecency of soil nutrient and improve soil organic matter, humus and overall soil productivity (Jenssen, 1993). Soil organic matter acts as "cement" for water holding clay and soil particles together, this contributing to the crumb structure of the soil providing resistance against soil erosion, binds micronutrient metal ions in the soil to check leaching out of surface soils. Organic constituents in the humic substances also act as plant growth stimulants (Jenssen, 1993; Palm et al., 1993). Biofertilizers are easy to apply, low-cost in nature and eco-friendly. A judicious combination of organic manures, inorganic fertilizers and biofertilizers might be helpful in obtaining high potato productivity and good soil health for sustainability. Therefore, an integrated nutrient management (INM) in which organic manures, inorganic fertilizers and biofertilizers are used simultaneously has been suggested as the most effective method to maintain a healthy and sustainable soil system as well as increasing crop productivity (Mondal et al.2008). There is evidence from field research that high and sustainable yields are possible with integrated use of organic fertilizers, inorganic fertilizers and biofertilizers (Singh et al., 2007).

The growth, production and quality of produced squash fruit are depending on the different 
agricultural treatments done during the growing season. Today's many farmers used different types of fertilization. An addition of adequate amounts of fertilizers in the form of bio fertilizers, organic manure or mixed of organic and mineral fertilizers to reduce the pollution of environmental and costs of mineral fertilizer.

Thus, the objectives of the present work aim to study the effect of mineral nitrogen fertilizer, organic and bio fertilization on fruit yield and its components of squash plants as well as chemical fruit quality to reduce the pollution of synthetic fertilizers on produced fruits and environment.

\section{Materials and Methods}

Two field experiments were carried out during the two successive summer seasons of 2016 and 2017 at the vegetable farm of the faculty of Agriculture, Moshtohor, Benha University. This experiment was carried out to investigate the response of Squash plant Cv. Eskandrani to mineral, organic and bio fertilization on vegetative growth, chemical composion, flowering behavior, fruit yield and its components as well as fruit quality. The texture of the experimental field was clay loamy with PH 7.8. Random soil samples were taken before planting for physical and chemical analysis (Table $1)$.

Table1. Physical and chemical analysis of the used soil as average of both seasons.

\begin{tabular}{|c|c|c|c|c|c|}
\hline \multicolumn{2}{|c|}{ Physical analysis } & \multicolumn{4}{|c|}{ Chemical analysis } \\
\hline & & \multicolumn{2}{|c|}{ Cations meg/l } & \multicolumn{2}{|c|}{ Anions meg/l } \\
\hline Coarse sand & $7.14 \%$ & $\mathrm{Ca}^{++}$ & 7.26 & $\operatorname{co} 3^{--}$ & zero \\
\hline Fine sand & $17.26 \%$ & $\mathrm{Mg}^{++}$ & 3.02 & $\mathrm{Hco}^{--}$ & 4.14 \\
\hline Silt & $23.20 \%$ & $\mathrm{Na}^{++}$ & 5.36 & $\mathrm{Cl}^{--}$ & 4.81 \\
\hline Clay & $52.40 \%$ & $\mathrm{~K}^{+} \quad 0$ & & $\mathrm{SO}^{--}$ & 7.52 \\
\hline Texture class & : clay loam. & Availa & le $\mathrm{N}$ & $21.3 \mathrm{mg} / \mathrm{kg}$ & \\
\hline Soil PH & $: 7.83$ & Availa & le $\mathrm{P}$ & $8.43 \mathrm{mg} / \mathrm{kg}$ & \\
\hline E.C, $\mathrm{ds} / \mathrm{m}$ & $: 1.65$ & Availa & le $\mathrm{K}$ & $117.4 \mathrm{mg} / \mathrm{kg}$ & \\
\hline Organic matter & : $2.16 \%$ & & & & \\
\hline
\end{tabular}

Seeds of squash CV Eskandaranie were sow in hills 30 cmapart on one side of ridge $70 \mathrm{~cm}$ width and $3.5 \mathrm{~m}$ long. Each experiment plot consisted of four ridges with an area of $9.8 \mathrm{~m}^{2}$. The experimental treatments of mineral, organic and bio fertilization in single or combined application were conducted as follows:-

1- $100 \%$ mineral nitrogen fertilizer from recommended dose $(200 \mathrm{~kg}$ ammonium nitrate per feddan).

2- $75 \%$ mineral nitrogen fertilizer from recommended dose plus $25 \%$ in the form of organic manure (compost).

3- $50 \%$ mineral nitrogen plus $50 \%$ organic manure.

$3-25 \%$ mineral nitrogen plus $75 \%$ organic manure.

4- $100 \%$ organic manure (compost).

6- $100 \%$ organic manure (compost) plus addition of phosphorine at rate of $500 \mathrm{~g} / \mathrm{fed}$ plus Nitrobein bio-

Table 2. Chemical properties of the used compost

\begin{tabular}{ccccccccc}
\hline Parameters & Det & $\begin{array}{c}\text { Ec } \\
\mathbf{d S . m}\end{array}$ & $\mathbf{p H}$ & Total & Total & Total & Total & C:N \\
erminations & $(\mathbf{1 : 5})$ & $\mathbf{1 : 5})$ & $\mathbf{C}$ \% & N \% & P \% & K \% & ratio \\
\hline First season & 2.73 & 6.71 & 21.98 & 1.01 & 0.68 & 1.29 & $18: 1$ \\
Second season & 2.82 & 6.83 & 22.54 & 1.50 & 0.59 & 1.64 & $19: 1$ \\
\hline
\end{tabular}

\section{Bio fertilizer treatments:}

A mixture of nitrobein + phosphorein contained efficient strains of nitrogen fixing bacteria (Azotobacter chroococcum) + phosphate dissolving bacteria(PDB) (Bacillus megaterium var phosphaticum) which were supplied by the department of Microbiology, Agric. Res. Center, fertilizer at rate of $400 \mathrm{~g} / \mathrm{fed}$. From each of them added once during season.

7- Bio- fertilizer only (phosphorein at rate $500 \mathrm{~g} / \mathrm{fed}$ plus nitrobein at rateof $400 \mathrm{~g} / \mathrm{fed})$.

8- $75 \%$ mineral nitrogen plus $25 \%$ organic manure (compost) plus bio- fertilizer (phosphorein + nitrobein)

9- $50 \%$ mineral nitrogen plus $50 \%$ organic plus biofertilization.

10- $25 \%$ mineral nitrogen plus $75 \%$ organic manure plus bio- fertilizer.

11- $100 \%$ mineral nitrogen plus bio fertilization (phosphorein at rate of $500 \mathrm{~g} / \mathrm{fed}$ plus Nitrobein at rate of $400 \mathrm{~g} / \mathrm{fed})$.

\section{Organic fertilizer treatments:}

Organic manure (compost) was added during soil preparation in both seasons. The chemical properties of the used compost are shown in Table 2.
Giza nitrobein was added at the rate of $400 \mathrm{~g} / \mathrm{fed}$, phosphorine at rate of $500 \mathrm{~g} / \mathrm{fed}$. The strains were characterized by a good ability to infect its specific host plant and by its high efficiency in N-fixation, phosphate solubilizing. 
Data recorded:--

1 - Fruit parameters:-

1-1 Physical fruit quality: fruit length, weight and diameter were measured for fruit sample (10 fruits) from each experimental plot.

\section{1-2Fruit yield:-}

Total yield, Total number of fruits per plant, Fruit yield/ plant, Total yield ton/fed

\section{2- Fruit chemical contents:}

2-1 Mineral chemical constituents of squash fruits:-

N, P, K and Total soluble solids T.S.S\%

2-2 Organic chemical constituents of squash fruits Total carbohydrates: Total sugars (total, reducingnon reducing sugars) were determined Statistical analysis according to A.O.C.A. (1990).

All obtained data were subjected to statistical analysis according to Gomez and Gomez (1991) and L.S.D multiple range tests at 5\% level was used to compare between treatment means.

\section{Results and Discussion}

\section{Physical fruit quality:-}

Table 3 indicate the effect of mineral nitrogen fertilizer, organic manure and bio fertilization on physical fruit quality of squash plant expressed as fruit length, diameter and weight during 2016 and
2017 seasons. All nitrogen fertilizer treatments had a significant effect on physical fruit quality except fruit diameter in both seasons. Which This did not reach the level of significance at 0.05 . The highest values of fruit length, diameter and weight were recorded from $100 \%$ mineral nitrogen of recommended dose, followed by $100 \%$ organic manure treatments, followed by $75 \%$ mineral nitrogen plus $25 \%$ organic manure. On the other hand the lowest values in first season refer to $25 \%$ mineral nitrogen $+75 \%$ organic manure + bio fertilizer with (phosphorein + nitrobein). In second season the highest values in fruit length and weight were resulted from $75 \%$ mineral nitrogen plus $25 \%$ organic manure plus bio fertilizer. The highest values in fruit diameter were recorded from $50 \%$ mineral nitrogen $+50 \%$ organic manure (compost) + bio fertilizer and $100 \%$ organic manure + bio fertilizer treatment. On the other hand, the lowest values for fruit length, diameter and weight were recorded from $100 \%$ organic manure treatment, $50 \%$ mineral nitrogen $+50 \%$ organic manure and bio fertilizer only, respectively, the highest values refer to organic manures increase the organic matter in the soil. They provided organic acids that help dissolve soil nutrients and make them available for plants. Application of organic manures improves the soil fertility, soil structure and moisture holding capacity.

Table 3. Effect of mineral nitrogen, organic and bio fertilization on physical fruit quality of squash plant during 2016 and 2017 seasons

\begin{tabular}{lcccccc}
\hline \multicolumn{1}{c}{ Characteristics } & $\begin{array}{c}\text { Fruit } \\
\text { length } \\
\text { Treatment }\end{array}$ & $\begin{array}{c}\text { Fruit } \\
\text { diameter } \\
(\mathbf{c m})\end{array}$ & $\begin{array}{c}\text { Fruit } \\
\text { weight } \\
(\mathbf{c})\end{array}$ & $\begin{array}{c}\text { Fruit } \\
\text { length } \\
(\mathbf{c m})\end{array}$ & $\begin{array}{c}\text { Fruit } \\
\text { diameter } \\
(\mathbf{c m})\end{array}$ & $\begin{array}{c}\text { Fruit } \\
\text { weight } \\
(\mathbf{g})\end{array}$ \\
\hline & \multicolumn{2}{c}{ First season } \\
\hline $\mathbf{1 0 0} \%$ mineral & 15.22 & 2.85 & 65.75 & 12.80 & 2.62 & 52.03 \\
$\mathbf{1 0 0} \%$ organic & 15.00 & 2.83 & 63.25 & 11.60 & 2.43 & 43.10 \\
only bio & 12.02 & 2.77 & 54.75 & 12.32 & 2.65 & 44.92 \\
$\mathbf{1 0 0} \%$ organic plus bio & 13.95 & 2.75 & 58.00 & 13.25 & 2.85 & 52.15 \\
$\mathbf{1 0 0} \%$ mineral plus bio & 11.73 & 2.67 & 62.75 & 14.25 & 2.77 & 61.63 \\
$\mathbf{7 5} \%$ mineral plus 25 \% organic & 14.88 & 2.80 & 62.88 & 13.38 & 2.60 & 49.38 \\
$\mathbf{5 0} \%$ mineral plus 50 \% organic & 13.90 & 2.65 & 59.25 & 13.57 & 2.55 & 51.20 \\
$\mathbf{2 5} \%$ mineral plus 75 \% organic & 13.20 & 2.62 & 58.25 & 12.63 & 2.62 & 48.53 \\
$\mathbf{7 5} \%$ mineral plus 25 \% organic plus bio & 12.60 & 2.62 & 57.25 & 16.17 & 2.75 & 64.72 \\
$\mathbf{5 0} \%$ mineral plus 50 \% organic plus bio & 11.35 & 2.60 & 54.75 & 15.45 & 2.85 & 58.13 \\
$\mathbf{2 5} \%$ mineral plus 75 \% organic plus bio & 11.13 & 2.55 & 54.00 & 14.45 & 2.65 & 53.10 \\
LSD & 3.15 & n.s. & 3.13 & 3.131 & n.s. & 4.53 \\
\hline
\end{tabular}

Bio fertilizer gave highest values may be it contains phosphate and nitrogen solubilizing bacteria produces organic and inorganic acids and $\mathrm{CO} 2$ Which dissolve the precipitate from phosphate and 1nitrogen to available in soil. Also increasing nitrogen rates in soil solution a round rooting zone caused an increasing in the solubility and availability of nutrients hence increasing the absorption of the nutritional elements in plant and therefore increased physical fruit quantity.
Shafeek et al. (2015) illustrated that the highest values of physical fruit quality expressed as fruit length, diameter, weight and size of fruits were significantly recorded by adding the highest level of NPK fertilizer (100\%) from recommended dose. Abdel- Nabi et al. (2016) stated that increasing mineral nitrogen fertilizer rate from 75 to 100 and $125 \mathrm{~kg} \mathrm{~N} /$ fed tended to increase fruit diameter and fruit size. Abdel- Nabi et al. (2016) indicated the mineral nitrogen, organic manure and foliar fertilization with bio fertilizers on cantaloupe plant 
had a significant effect on fruit diameter in first season. While number of fruits/ plant in both season and fruit diameter in the second season did not showed significant effect. And results agreement with Taha et al. (2011), Ragab (2016), Kevineifediyi et al. (2017), Satish et al. (2017).

Fruit yield and its components:-

Data recorded in Table 4 show the effect of mineral nitrogen fertilizer, organic manure (compost) and bio fertilizer on produced fruit yield of squash plants and its components expressed as fruit number per plant, fruit yield per plant and total fruit yield per feddan during both seasons of study.

The same data presented in Table 4 show clearly that there were a significant differences among the studied nitrogen fertilizer treatments on all determined yield and its components during the two seasons of growth. In this concern, fertilizing squash plants with $100 \%$ mineral nitrogen fertilizer only reflected the highest values of number of fruit per plant, fruit yield per plant and total fruit yield per feddan compared with other nitrogen fertilizer treatments. In addition, fertilizing squash plants with $100 \%$ organic manure ranks the second season in total produced fruit yield and its components followed by fertilizing plants with bio fertilizer only. On the other hand, the lowest values for number of fruits per plant, fruit yield per plant and total fruit yield per feddan were recorded from $25 \%$ mineral nitrogen fertilizer $+75 \%$ organic manure (compost) + bio fertilizer with (nitrobein + phosphorein) obtained results are true during both seasons of study. From this results, the higher produced fruit yield and its components of squash plants from fertilizing plants with $100 \%$ mineral nitrogen and $100 \%$ organic manure compared with the best vegetative growth traits (Table,1) and good physical fruit quality (Table, 4) which reflected on higher produced fruit yield and its components. AbdelNabi et al.(2016) indicated the increasing mineral nitrogen fertilizer rates from 75 to 100 and $125 \mathrm{~kg} \mathrm{~N} /$ fed tended to increase yield and its components, thus the highest values of these characters were resulted from adding the highest rate of nitrogen fertilizer $(125 \mathrm{~kg} \mathrm{~N} / \mathrm{fed})$ in both seasons. Shafeek et al. (2016) illustrated the application of nitrogen fertilizer at 100 and $150 \mathrm{~kg} \mathrm{~N} /$ fed increased total yield ton /fed. However, the high level of $\mathrm{N}$ fertilizer $(150 \mathrm{~kg} / \mathrm{fed})$ increased total yield and its components compared with the medium level (100kg Nfed). Baselet al. (2014) indicated that the use of organic fertilizer compost on cucumber increased crop productivity (7005 kg/dunum). And Eifediyi et al. (2010), Hammadet al. (2016), Kevienifediyi et al. (2017).

Table 4. Effect of mineral nitrogen, organic and bio fertilization on yield and its components of squash plant during 2016 and 2017 seasons

\begin{tabular}{|c|c|c|c|c|c|c|}
\hline $\begin{array}{c}\text { Characteristics } \\
\text { Treatment }\end{array}$ & $\begin{array}{c}\text { fruit } \\
\text { number/ } \\
\text { plant }\end{array}$ & $\begin{array}{l}\text { Plant } \\
\text { yield } \\
\text { (gm) }\end{array}$ & $\begin{array}{l}\text { Total } \\
\text { yield/ } \\
\text { fed. } \\
\text { (ton) }\end{array}$ & $\begin{array}{c}\text { fruit } \\
\text { number/ } \\
\text { plant }\end{array}$ & $\begin{array}{l}\text { Plant } \\
\text { yield } \\
\text { (gm) }\end{array}$ & $\begin{array}{l}\text { Total } \\
\text { yield } \\
\text { /fed. } \\
\text { (ton) }\end{array}$ \\
\hline & \multicolumn{3}{|c|}{ First season } & \multicolumn{3}{|c|}{ Second seaon } \\
\hline $100 \%$ mineral & 9.59 & 565.0 & 6.59 & 14.18 & 738.0 & 8.60 \\
\hline $100 \%$ organic & 8.87 & 555.0 & 6.47 & 13.56 & 652.5 & 7.61 \\
\hline only bio & 8.53 & 535.5 & 6.24 & 13.11 & 589.0 & 6.87 \\
\hline $100 \%$ organic + bio & 8.44 & 519.0 & 6.05 & 10.32 & 538.5 & 6.28 \\
\hline $100 \%$ mineral + bio & 8.22 & 516.0 & 6.01 & 8.64 & 532.5 & 6.21 \\
\hline $75 \%$ mineral $+25 \%$ organic & 7.76 & 467.4 & 5.45 & 10.75 & 531.0 & 6.19 \\
\hline $50 \%$ mineral $+\mathbf{5 0} \%$ organic & 7.86 & 465.9 & 5.43 & 10.29 & 527.0 & 6.14 \\
\hline $25 \%$ mineral $+75 \%$ organic & 7.50 & 436.9 & 5.09 & 9.69 & 496.5 & 5.79 \\
\hline $75 \%$ mineral $+25 \%$ organic + bio & 7.60 & 434.0 & 5.06 & 7.50 & 485.4 & 5.66 \\
\hline $50 \%$ mineral $+\mathbf{5 0} \%$ organic + bio & 8.70 & 376.7 & 4.39 & 7.55 & 439.4 & 5.12 \\
\hline $25 \%$ mineral $+75 \%$ organic + bio & 6.75 & 365.0 & 4.25 & 7.30 & 414.5 & 4.83 \\
\hline LSD & 0.84 & 62.7 & 0.38 & 0.33 & 112.7 & 0.18 \\
\hline
\end{tabular}

Mineral chemical constituents of squash fruits:-

Data at Table 5 show the effect of mineral nitrogen, organic manure and bio fertilizer (phosphorein + nitrobein) on mineral chemical constituents of squash fruits (N\%, K\%, P\% and TSS) during the two seasons of growth. There were significant differences between the used nitrogen fertilizer treatments in all studied mineral chemical constituents of squash fruits. Data recorded in Table
6 indicated that fertilizing squash plants with $25 \%$ mineral nitrogen fertilizer $+75 \%$ organic manure gave the highest values of nitrogen phosphorus and potassium contents in squash plant fruits. Whereas, using $100 \%$ organic manure + bio fertilizer with (phosphorein + nitrobein) gave the highest content of total soluble solids. On the other hand, the lowest values of total nitrogen and total soluble solids content of squash plant fruit were obtained from 
using $75 \%$ mineral nitrogen fertilizer $+25 \%$ organic manure + bio fertilizer (phosphorein + nitrobein), for phosphaorus $\%$ from using $100 \%$ mineral nitrogen fertilizer + bio fertilizer and using 50\% mineral nitrogen fertilizer $+50 \%$ organic manure (compost) + bio fertilizer for potassium $\%$. Thes is true during the frist season. Meanwhile during the second season, the highest values for nitrogen percentage $(2.66 \%)$ were obtained from using $25 \%$ mineral nitrogen fertilizer $+75 \%$ organic manure + bio fertilizer, for phosphorus percentage $(1.30 \%)$ from using $75 \%$ mineral nitrogen fertilizer $+25 \%$ organic manure for each of potassium percentage $(6.50 \%)$ and total soluble solids (5.00) from using $100 \%$ mineral nitrogen fertilizer only, on the contrary, the lowest values for nitrogen percentage $(2.23 \%)$ were obtained from using $50 \%$ mineral nitrogen fertilizer $+50 \%$ organic manure, for phosphorus percentage $(0.47 \%)$ from using $50 \%$ mineral nitrogen fertilizer $+50 \%$ organic manure + bio fertilizer (phosphorein + nitrobein), and for total soluble solids (3.33) from using $25 \%$ mineral nitrogen fertilizer $+75 \%$ organic manure + bio fertilizer. Such in the concentration of macro- elements in squash fruits as a results of mineral, organic and bio fertilizer application may be due to the main role of such fertilizers in increasing the concentration of macro and micro elements at rooting zone which consequently increased the uptake of such nutrients by plant and transferred to stored in the fruits. Sabreenet al. (2015) indicated the fertilization of summer squash plant with nitrogen at 45,60 and $75 \mathrm{~kg} /$ fed had no significant effect on T.S.S\%, P and K content of fruits, while ,application of mineral nitrogen at rate of $75 \% \mathrm{~kg} / \mathrm{fed}$ showed significant effect on $\mathrm{N}$ content in the fruits. Application of chitosan at the rate of $0.01 \mathrm{~g} / \mathrm{L}$ had significant effect on T.S.S, $\mathrm{N}$ and $\mathrm{P}$ content. On the other hand, all chitosan treatment had no significant effect on $\mathrm{K}$ content in the fruits. And Shafeeket al. (2015), Abdel- Nabiet al. (2016).

Table 5. Effect of mineral nitrogen, organic and bio fertilization on mineral chemical contents of squash plant fruits during 2016 and 2017 season

\begin{tabular}{|c|c|c|c|c|c|c|c|c|}
\hline Characteristics & $\begin{array}{c}\mathbf{N} \\
(\%)\end{array}$ & $\begin{array}{c}\mathbf{P} \\
(\%)\end{array}$ & $\begin{array}{c}\mathbf{K} \\
(\%)\end{array}$ & $\begin{array}{c}\text { TSS } \\
\%\end{array}$ & $\begin{array}{c}\mathbf{N} \\
(\%)\end{array}$ & $\begin{array}{c}\mathbf{P} \\
(\%)\end{array}$ & $\begin{array}{c}K \\
(\%)\end{array}$ & $\begin{array}{c}\text { TSS } \\
\%\end{array}$ \\
\hline & \multicolumn{4}{|c|}{ First season } & \multicolumn{4}{|c|}{ Second season } \\
\hline $100 \%$ mineral & 2.46 & 0.56 & 5.30 & 4.33 & 2.53 & 0.93 & 6.50 & 5.00 \\
\hline $100 \%$ organic & 2.30 & 0.53 & 5.60 & 4.33 & 2.36 & 1.10 & 6.46 & 4.33 \\
\hline only bio & 2.53 & 0.76 & 5.73 & 5.00 & 2.33 & 0.47 & 5.83 & 4.00 \\
\hline $100 \%$ organic plus bio & 2.50 & 0.70 & 6.10 & 5.66 & 2.56 & 0.63 & 5.90 & 4.00 \\
\hline $100 \%$ mineral plus bio & 2.40 & 0.50 & 4.96 & 4.33 & 2.56 & 0.67 & 6.03 & 5.00 \\
\hline $75 \%$ mineral plus $25 \%$ organic & 2.36 & 0.66 & 5.10 & 5.33 & 2.23 & 1.30 & 5.43 & 3.66 \\
\hline $50 \%$ mineral plus $50 \%$ organic & 2.66 & 0.83 & 5.56 & 4.33 & 2.23 & 1.00 & 6.16 & 4.00 \\
\hline $25 \%$ mineral plus $75 \%$ organic & 2.66 & 0.86 & 6.10 & 5.33 & 2.36 & 0.93 & 6.13 & 4.00 \\
\hline $75 \%$ mineral plus $25 \%$ organic plus bio & 2.20 & 0.76 & 5.23 & 4.33 & 2.26 & 0.90 & 6.23 & 4.00 \\
\hline $50 \%$ mineral plus $50 \%$ organic plusbio & 2.46 & 0.53 & 4.60 & 4.33 & 2.36 & 1.10 & 5.36 & 4.00 \\
\hline $25 \%$ mineral plus $75 \%$ organic plusbio & 2.60 & 0.53 & 5.63 & 5.33 & 2.66 & 1.10 & 6.20 & 3.33 \\
\hline LSD & 0.28 & 0.25 & 0.79 & 1.20 & 0.29 & 0.194 & 1.018 & 1.40 \\
\hline
\end{tabular}

Organic chemical constituents of squash fruits:-

Data presented in Table 6 indicated that fruit content of total carbohydrate, reducing, non-reducing and total sugars as affected by mineral nitrogen, organic manure. And bio fertilizer. There were a significant difference in assayed total carbohydrates, reducing, non-reducing and total sugars content between nitrogen fertilizer treatments, expect nonreducing sugars in the second season only which did not reach the level of significance at 0.05 . Data in Table 6 show Cleary the highest value of total carbohydrate content of squash fruits $24.13 \mathrm{~g} /$ 100 g.d.w. were scored by using $50 \%$ mineral nitrogen fertilizer $+50 \%$ organic manure + bio fertilizer in the first season where as in the second season the plants fertilized by $25 \%$ mineral nitrogen $+75 \%$ organic manure gave the highest carbohydrate content (23.37 g./100 g. d.w). In addition, the highest values of total sugars $75 \%$ mineral nitrogen fertilizer $+25 \%$ organic manure, for reducing sugars by using
$100 \%$ organic manure only and for non- reducing sugars by using $75 \%$ mineral nitrogen fertilizer + $25 \%$ organic manure + bio fertilizer. On the other hand, the lowest values of total carbohydrates were obtained from the treatment $100 \%$ mineral nitrogen fertilizer only for total and reducing sugars from using $75 \%$ mineral nitrogen $+25 \%$ organic manure bio fertilizer (phosphorein + nitrobein), whereas for non- reducing sugars from using $75 \%$ mineral nitrogen $+25 \%$ organic manure only during the first season. Meanwhile in the second season the highest value for total carbohydrates content in squash fruits were obtained from using $25 \%$ mineral nitrogen + $27 \%$ organic manure and for total, reducing and nonreducing sugars from using \% organic manure only. On the contrary the lowest value for total carbohydrates was obtained from using $100 \%$ mineral nitrogen + bio fertilizer, for total sugars and non- reducing from using $75 \%$ mineral nitrogen + $25 \%$ organic manure + bio fertilizer, and for reducing 
sugars from $50 \%$ mineral nitrogen $+50 \%$ organic manure (compost). Such results may be due to the main role of nitrogen fertilizer with photosynthesis products in plant metabolism and produced sugars and carbohydrates.such results are in agreement with thoses reported by Oloyeda et al. (2012),Shafeeket al. (2015) and Abdel-Nabi et al.(2016).

Table 6. Effect of mineral nitrogen, organic and bio fertilization on organic Chemical constituents of squash plant fruits during 2016 and 2017 seasons.

\begin{tabular}{|c|c|c|c|c|c|c|c|c|}
\hline $\begin{array}{l}\text { Characteristics } \\
\text { Treatment }\end{array}$ & $\begin{array}{c}\text { Total } \\
\text { carbohy } \\
\text { drate } \\
\text { g/100g.d. } \\
\text { w. } \\
\end{array}$ & $\begin{array}{l}\text { Total } \\
\text { Sugars }\end{array}$ & $\begin{array}{l}\text { Reducing } \\
\text { sugar }\end{array}$ & $\begin{array}{l}\text { Non- } \\
\text { reducing } \\
\text { sugars }\end{array}$ & $\begin{array}{c}\text { Total } \\
\text { Carbohy } \\
\text { drate } \\
\text { g/100g } \\
\text { d.w. }\end{array}$ & $\begin{array}{l}\text { Total } \\
\text { sugars }\end{array}$ & $\begin{array}{l}\text { Reducing } \\
\text { sugars }\end{array}$ & $\begin{array}{l}\text { Non- } \\
\text { reducing } \\
\text { sugars }\end{array}$ \\
\hline & \multicolumn{4}{|c|}{ First season } & \multicolumn{4}{|c|}{ Second season } \\
\hline $100 \%$ mineral & 15.83 & 0.52 & 0.34 & 0.18 & 21.10 & 0.46 & 0.29 & 0.17 \\
\hline $100 \%$ organic & 23.67 & 0.93 & 0.78 & 0.15 & 20.80 & 0.77 & 0.56 & 0.20 \\
\hline Bio & 19.63 & 0.49 & 0.34 & 0.15 & 23.20 & 0.40 & 0.24 & 0.15 \\
\hline $100 \%$ organicplus bio & 19.67 & 0.42 & 0.20 & 0.22 & 15.27 & 0.43 & 0.2900 & 0.14 \\
\hline $\begin{array}{l}100 \% \text { mineralplus bio } \\
75 \% \text { mineral }\end{array}$ & 19.80 & 0.83 & 0.66 & 0.17 & 11.87 & 0.43 & 0.28 & 0.15 \\
\hline $\begin{array}{l}\text { plus } 25 \% \text { organic } \\
50 \% \text { mineral }\end{array}$ & 21.37 & 0.91 & 0.77 & 0.14 & 12.47 & 0.30 & 0.11 & 0.18 \\
\hline $\begin{array}{l}\text { plus } 50 \% \text { organic } \\
25 \% \text { mineral }\end{array}$ & 21.13 & 0.92 & 0.77 & 0.15 & 15.47 & 0.27 & 0.09 & 0.17 \\
\hline $\begin{array}{l}\text { plus } 75 \% \text { organic } \\
75 \% \text { mineral plus } 25 \%\end{array}$ & 22.10 & 0.56 & 0.33 & 0.23 & 23.37 & 0.40 & 0.26 & 0.13 \\
\hline $\begin{array}{l}\text { organic plus bio } \\
\mathbf{5 0} \% \text { mineral plus } 50 \%\end{array}$ & 22.13 & 0.43 & 0.19 & 0.24 & 20.23 & 0.26 & 0.15 & 0.11 \\
\hline $\begin{array}{l}\text { organic plusbio } \\
25 \% \text { mineral plus } 75 \%\end{array}$ & 24.13 & 0.66 & 0.52 & 0.14 & 21.73 & 0.33 & 0.16 & 0.16 \\
\hline organic plusbio & 22.37 & 0.76 & 0.54 & 0.22 & 18.53 & 0.30 & 0.10 & 0.19 \\
\hline LSD & 3.35 & 0.35 & 0.37 & 0.053 & 2.802 & 0.13 & 0.13 & 0.17 \\
\hline
\end{tabular}

\section{References}

A.O.A.C (1975). (Association of official agriculture chemists).Official Methods analysis, 12 Th Ed., published by A.O.A.O., Washington, D.C.

A.O.A.C. (1980). Official methods of analysis 13 th Ed. Association of Official Analytical Chemists. Washington. D.C., U.S.A.

Abdel-Nabi, H. M. A., K. D. Kawther, E. I. ElGamily and Y. F. E. Imryed (2014).Impact of mineral, organic and bio fertilization on growth, yield and quality of cantaloupe. J. Plant Production, Mansoura Unv. (11): 1777-1794.

Basel, N., M. Sami. Effect of organic and inorganic fertilizers application on soil and Cucumber (Cucumis Sativa L.) plant productivity (2014). J. inter. Of Agric. And Foresty 4(3): 166-170.

Ehiokhlien, K. E., R. U., Samson, A. E., Henry, A. O., Kameel and F. O., Phillip (2017).Performance of watermelon (Citrulluslanatus L.) in response to organic and NPK fertilizers. J. Agric. Enviro. 9: 5-17

Eifediyi, E.K. and S.U.Remison.(2010). Growth and yield of cucumber (cucumissativus L.) as influenced by farmyard manure and inorganic fertilizer. J. plant Breed. Crop Sci. 2(7):216-220.
EL-Kader; P. Robin; N. Akkal-Corfini and L. AbdEIRahman (2009). Effects of different organic and inorganic fertilizers on cucumber yield and some soil properties. World J. Agric. Sci., 5 (4): 408-414. N

El-Nagar, E.M. (1996).Effect of applying some organic residues to sandy calcareous soils on growth and composition of some plants. M. Sc. Thesis, Fac. Agric. Mansoura Univ., Egypt.

Etich, O.K.A.N.Niyokuri, J.J.Rono, A.Fashaho and J.O.Ogweno .(2013). Effect of different rates of nitrogen fertilizer on the growth and yield of zucchini (CucurbitaPepoCv.Diamant L.) hybrid f1 in rawandan high altitude zone. International .J.Agric .Crop Sci.5 (1): 54-62.

Gomez, K. A. and A. A. Gomez (1991).Statistical procedures for Agri. Res. John Willey and sons. New York.

Hammad, K. H. A and H. A. Hussein (2016).Effect of NPK and chicken manure on the growth productivity and som growth components of squash (Cucurbitapepo L.).ARPN J. of Agric. And Bio sci. 11(6): 230-235.

Kathiravan, K., G. Vengedesan, S. Singer, B. Steinitz, H.S. Paris and V. Gaba. (2006). Adventitious rggention in vitro occurs a wide spectrum of squash (cucurbitapepo) genotypes. Plant cell tissue organ cult., 85:285-295. 
Kostalova, Z. z., A. Hromadkova and Ebringerova (2009).Chemical evaluation of seeded fruit biomass of oil pumpkin(cucurbitapepo). Chemical paper, 63:406-413.

Lindani, N. and Brutsch, M.O. (2012).Effects of the integrated use of effective micro-organisms, compost and mineral fertilizer on greenhousegrown tomato.Afric. J. Plant Sci., 7(3): 120-124. Mahmoud, E.; N. Abd

Mohammad, B. E, R. Ehsan and A. Amin (2011).Climatic suitability of growing summer squash (cucurbitapepo) as a medicinal plant in Iran. Not Sci. Biol., 3(2):39-46.

Obalum, S.E., M.M; Buri. J. C., Nwite. L., Hermansah. Y., Watanabe. C. A., Igwe and Wakatsuki T. (2012). Soil degradation-induced decline in productivity of Sub-saharan African Soils: The prospects of looking downwards the lowlands with the SawahEcotechnology, Applied and Evvirimental soil Scince. Article ID 673926, 10 pages doi: 10.1155/2012/673926.

Odebode, A.A. and C.A. Fajinmi (2009). Effect of poultry manure on pepper veinal mottle virus (PVMV), yield and agronomic parameters of pepper (Capsicum annuum L.) in Nigeria. EAJS., 1(1):104-111 (C F Computer Search)

Oloyede, F.M. (2012). Growth, yield and antiuoxidant profile of pumpkin (CucurbitapepoL.) leafy vegetable as affected by NPK compound fertilizer .J. Soil Sci and plant nutrition, 12(3):397-387.

Ragab, T (2016). Magesium and phosphorien application improve the efficiency of growth and productivity of squash plants grown on sandy calcareous soil. J. Of Advanced Botany and zoology (4): 1-6.

Sakr, M.T. ; H.M. Abd El-Salam; M.L. Atta and M.A. Abd- El-Aal (2013).Alleviating the harmful effect of salinity stress on soybean plants by using some promoters. J. of Plant Production, Mansoura Univ., 4(2): 205-218
Satish, S. B., U.S., Bose and S. S., Singh (2017).Impact of different organic and inorganic fertilizer on sustainable production of Bottle Gourd. J. inter. Of pure \& applied Bio. Sci. 5 (2): 1089-1094.

Shafeek, M.R., A. M. Shaheen, E. H. Abd ElSamad, Fatma A. Rizk and Faten S. Abd ElAla (2015). Respones of growth, yield and fruit quality of cantaloupe plants (Cucumismelo L.) to organic and mineral fertilization. J. Middle East of Agric. Res., 5(1): 76-82.

Shafeek, M.R.,Y.I. Helmy and A.A. Ahmed .(2016).Productivity of squash plant to mineral and bio -nitrogen fertilizers on plant growth, total yield and leaves mineral content on a sandy soil. International, J.ChemTech. Research.9 (3)66-75.

Shehata, S. A. ; Z. F. Fawzy and EL R. ElRamady (2012). Response of cucumber plants to foliar application of chitosan and yeast under greenhouse conditions. Australian J. of Basic and Applied Sci., 6(4): 63-71.

Shehata, S.A. ; Y.M. Ahmed; E.A. Shalaby and O.S. Darwish (2011). Influence of compost rates and application time on growth, yield and chemical composition of snap bean (Phaseolus vulgaris L.). Australian J. Basic and Appl. Sci., 5(9): 530-536.

Swelam, W.M. (2012). Effect of organic fertilizer, biofertilizer and some foliar application treatments on the yield and quality of sweet pepper. M.Sc. Thesis, Fac. of Agric., Mansoura Univ., Egyp

Taha, Z. S., H. M. Ghurbat and A. T. Jiyan (2011).Effect of bio and organic fertilizers on growth, yield and fruit quality of summer squash.Sarhad J. Agric. 27(3): 377-383.

Tamer, CE, B. Nceday, As. Parseker, S. Yonak and OU.Coupr (2010).Evaluation of several quality criteria of low calorie pumpkin dessert. Not Bot HortAgrobotCluj., 38:76- 80. 


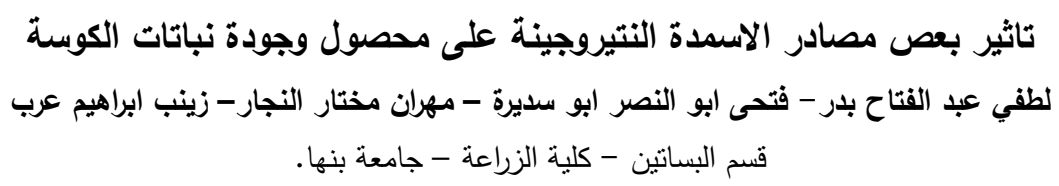

أجريت تجربتان حقلينان خلال الموسم الصيفى لعامى 2016و 2017 بمزرعة الخضر بكلية الزراعة بمشتهر - جامعة بنها لدراسة استجابة نباتات

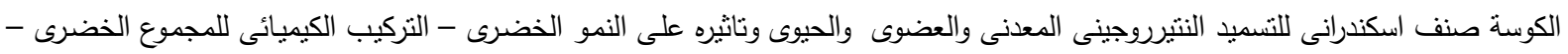

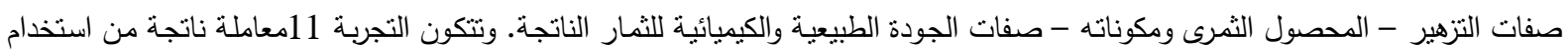
التسميد النتروجينى المعدنى والعضـوى والحيوى امـا منفردا او الخلط بيينهماوضــت النتائج المتحصل عليها انهـ توجد اختلافـات معنويـة بين

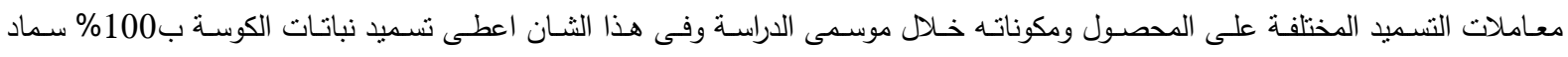
نتيروجينى معدنى الى اعلى عدد من الثمار/النبات واعلى محصول ثمرى للنبات الواحد واكبر محصول كلى للفدان وذللك بالمقارنة بباقى معاملات التسميد الاخربادت معاملات التسميد النتيروجينى الى تاثير معنوى واضـح على صفات الجودة الطبيعية للثمار خلال موسمى النمو حيث تم الحصول على اعلى القيم بالنسبة لطول - قطر - منتسط وزن الثمرة عند تسميد نباتات الكوسة ب100\% 100 تسميد معدنى بالمعدل الموصى بـه يليه

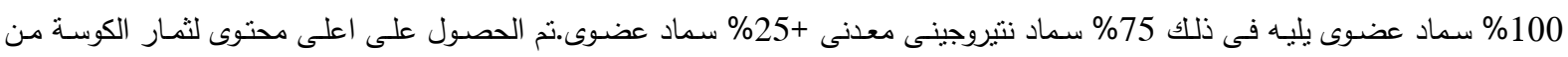
الكربوهيدرات الكلية بنسميد النباتات ب50\% سماج معدنى +50 سماد عضوى +السماد الحيوى وذلك فى موسم النمو الاول بينما كان اعلى محتوى

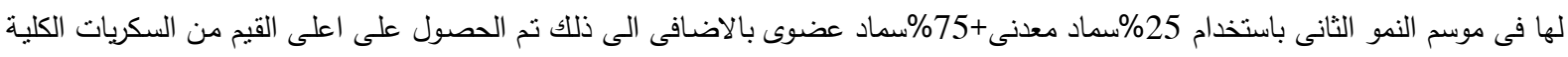

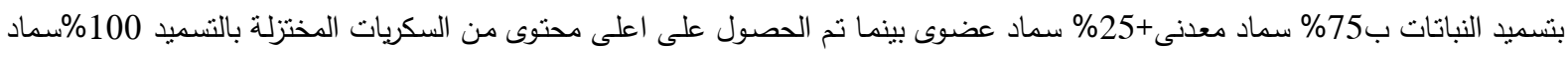

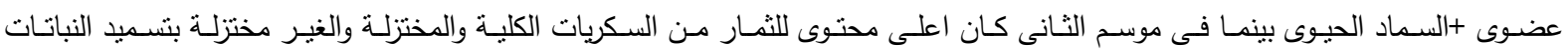
ب100\%سمادد عضوى فقط. 